\title{
The Effort to Develop Junior High School Students Self-Esteem Through Giving Positive Feedbacks
}

\author{
Dupri Dupri*, Novia Nazirun \\ Physical Education, Faculty of Teacher Training and Education \\ Islamic University of Riau \\ Riau, Indonesia \\ *dupri@edu.uir.ac.id
}

\begin{abstract}
A student has a sense of being interested in doing learning activities, while a good self-esteem will give students confidence in conducting learning activities. This study was aimed at developing the students' self-esteem through providing positive feedbacks. The method used in this study was an experimental method with the Pre-test and Post-test Control Group Design. In this study, the authors tried to find out the effect of giving positive feedbacks on junior high school students' self-esteem. The samples of this study were 93 people. The level of students' self-esteem was measured by using a questionnaire. The data analysis was administered by using $t$ test. The results of this study found that the significance values of the $t$ test were 0,000 for the Positive Feedback and $\mathbf{0 . 0 0 2}$ for the neutral feedback. Giving a positive feedback will have a good influence for developing self-esteem.
\end{abstract}

\section{Keywords: feedback, self-esteem}

\section{INTRODUCTION}

Physical education will provide opportunities for students to develop self-confidence, develop personal values through physical activity both individually and in groups [1-3]. The development of self-confidence in students when learning is felt very necessary as a form of student character development in everyday life later. In this study, self-confidence was given the term self-esteem.

Self-esteem is defined in terms of self-confidence even though it does not fully describe the true meaning. Self-esteem is self-acceptance, by oneself related that we are worthy, valuable, capable and useful no matter what has happened, is or will happen. The growth of feelings I can and I am valuable is the core of the understanding of self-esteem [4-6]. Self-esteem is the collection of beliefs or feelings that we have about ourselves, or our "self-perception." How do we define ourselves influences or motivations, attitudes, and behaviours and effect our emotional adjustments [7]. The point is that selfesteem is a collection of beliefs or feelings about ourselves or our perception of ourselves about motivation, attitudes, behaviour, and emotional adjustments that affect us.

A good physical education program will provide opportunities for students to develop self-confidence, develop personal values through physical activities both individually and in groups [8-10]. When that goal is achieved, it enables children to acquire and apply knowledge about physical activity, growth and development, aesthetic and social development, develop positive attitudes, develop social skills to communicate effectively with others [8]

Opportunities and benefits to be gained by students will be achieved if the physical education teacher is able to act in accordance with their functions and roles in developing the potential of students. Including when trying to develop healthy self-esteem in students. One way to develop healthy selfesteem is through effective communication. The most important indicators of effective communication are being straightforward, listening, and feeling the feelings of others [11-13]

A good teacher must be forthright in assessing students abilities by telling the truth in a way that does not make students worse off. For example the teacher must avoid the words "you can't" to students, but expressed the word "can't" when students have not been able to carry out the task of moving in accordance with teacher expectations. The most important thing is that the teacher still has a stance that is consistent with his speech and behaviour. A good physical teacher is a teacher who wants to hear and pay attention to everything expressed by students in order to improve the learning process. A good physical teacher is someone who is able to accept the feelings of others, including students feelings.

The function of Feedback is to provide motivation, reinforcement $[14,15]$ or punishment [8]. Reinforcement means any event that increases the probability that a particular response will reoccur under similar consequences [8]. Reinforcement is the reinforcement of events or activities that have been carried out so that these activities can still be maintained or provide a similar response and the next activity can be increased again. In terms of providing reinforcement states reinforcement is the use of reward and punishment that increases or decreases the likelihood of similar responses occurring in the future [11]. That reinforcement can use rewards or punishments that are very likely to increase or decrease similar responses that occur in the next period. Awards are not always in the form of objects as gifts, but can be through expressions. For example the physical teacher's expression that says "Your pitch is good, try throwing it at a farther target!" Whereas punishment is more about giving a bad assessment of what students are doing. For example in the phrase "Throw you are reckless, do not just throw!". 
Provision of feedback must be tailored to the needs of students. Student needs are related to the level of psychosocial development of students. In the development of students in adolescence who sometimes have desires of excessive attention or even want to be given the widest possible freedom, the teacher must be careful to provide feedback for improvement or correction of mistakes made by students. The lack of the type of feedback given will have an impact on feelings of discomfort, pessimism, lack of motivation, or lack of selfesteem because they always get a warning from the teacher. For this reason the characteristics of students must receive important attention when the teacher will provide feedback.

The characteristics of junior high school students (13-16 years) belong to early adolescence. The general characteristic of adolescence is to look at things from the subjective towards the objective $[16,17]$. Further stated that adolescents during school children are generally required to be able to do or complete something well and perfectly [16]. The ability to carry out tasks is a belief in their abilities. If not, then there will be a feeling of inferiority (inferiority) or self-esteem is very low which will be brought to the next level of development. Adolescence has shown the process of fulfilling needs at the stage of appreciation and self-realization (Maslow's Theory of Needs), and has shown the direction of certain tendencies that will colour the archetype of his personality [18].

The absence of a comparison of positive feedback with neutral feedback on physical education learning in previous studies so that researchers find the purpose of this study to see the effect of giving positive feedback with neutral feedback on the development of students' self-esteem in physical education learning.

\section{METHOD}

Method used in research is an experimental method. This study was designed to develop students' self-esteem in different classes, namely 2 classes with 2 types of giving feedback (positive feedback and neutral feedback). The design of this study is Pre-test and Post-test Control Group Design. This research lasted for 2 months, carried out on physical education learning in schools with the number of meetings 12 meetings in 80 minutes / meeting, 2 times per week.

Considering the population in this study is large and the sample to be used is all subjects in the learning group (intact group) because the subject in the study group cannot be moved so the sample selection is not randomly selected. The appropriate sampling technique is Cluster Random Sampling. To determine which class will be used as a sample, random IX1-IX4 classes are taken. The sample of this research is class IX 1, and IX 4. The class which will get Positive feedback and neutral feedback is also selected randomly.

The tool for obtaining information or collecting data in this study is a self-esteem questionnaire. The same questionnaire will be tested at the pre-test and post-test that have been tested for validity and reliability. The analysis used in this study was paired samples t test.

\section{RESULTS AND DISCUSSION}

TABLE I. PAIREd SAMPles STATISTICS

\begin{tabular}{|ll|c|c|c|c|}
\hline & Mean & N & $\begin{array}{c}\text { Std. } \\
\text { Deviation }\end{array}$ & $\begin{array}{c}\text { Std. } \\
\text { Error } \\
\text { Mean }\end{array}$ \\
\hline Pair 1 & Pretest Positive & 82.0000 & 33 & 4.46514 & .77728 \\
& Posttest Positive & 87.6667 & 33 & 3.27554 & .57020 \\
Pair 2 & Pretest Neutral & 79.3636 & 33 & 3.69813 & .64376 \\
& Posttest Neutral & 81.9697 & 33 & 3.85264 & .67066 \\
\hline
\end{tabular}

Paired Samples Test samples was done in order to determine whether there are differences in Self-Esteem students between pre-test and post-test in the group Positive Feedback and see how much influence Positive Feedback enhances the development of Self-Esteem healthy in junior high school students.

From the descriptive statistical table.1, the average value of post-test the group Positive Feedback is higher than pre-test the group Positive Feedback. The average value in post-test is the group Positive Feedback 82,000 while the average in pre-test is the group Positive Feedback 87,667, which means, there are differences in the level of development of Self-Esteem students before and after the group Positive Feedback.

From table 1. Descriptive statistics, the average value of the post-test group Neutral Feedback is higher than the pre-test group Neutral Feedback. The average value in the post-test group was Neutral Feedback 81,969 while the average in pretest was the group Neutral Feedback 79,363, which means that there were differences in the level of development of SelfEsteem students before and after in the group Neutral Feedback.

TABLE II. PAIRED SAMPLES CORRELATIONS

\begin{tabular}{|cll|c|l|c|}
\hline & \multicolumn{2}{|c|}{$\mathbf{N}$} & Correlation & Sig. \\
\hline Pair 1 & $\begin{array}{l}\text { Pretest Positive \& Posttest } \\
\text { Positive }\end{array}$ & 33 & .760 & .000 \\
Pair 2 & $\begin{array}{l}\text { Pretest Neutral \& Posttest } \\
\text { Neutral }\end{array}$ & 33 & .347 & .048 \\
\hline
\end{tabular}

Seeing group Positive Feedback was influential to the attitude of Self-Esteem of students can be seen in the table. 2 columns correlation whose value is 0.760 with sig. 0.000 and large effect is $57.76 \%$ so that the conclusions obtained are $\mathrm{H} 0$ is rejected. This means that there is an effect of providing positive feedback on the development of self-esteem healthy in junior high school students.

Whereas to prove that the group Neutral Feedback has an effect on attitudes Self-Esteem students we can see in table 2 the column correlation whose value is 0.347 with sig. Great effect 0.048 and amounted to $12.041 \%$ so that the conclusions obtained are $\mathrm{HO}$ is rejected. This means that there is an effect of providing Neutral Feedback on the development of self-esteem healthy in junior high school students. 
TABLE III $\quad$ PAIRED SAMPLES TEST

\begin{tabular}{|c|c|c|c|c|c|c|c|}
\hline & \multicolumn{3}{|c|}{ Paired Differences } & \multirow[t]{3}{*}{$\mathbf{t}$} & \multirow[t]{3}{*}{ df } & \multirow{3}{*}{$\begin{array}{c}\text { Sig. } \\
(2- \\
\text { tailed }) \\
\end{array}$} \\
\hline & & \multirow[t]{2}{*}{ Mean } & \multicolumn{2}{|c|}{$\begin{array}{l}95 \% \text { Confidence } \\
\text { Interval of the } \\
\text { Difference }\end{array}$} & & & \\
\hline & & & Lower & Upper & & & \\
\hline $\begin{array}{l}\text { Pair } \\
1\end{array}$ & $\begin{array}{l}\text { Pretest } \\
\text { Positive } \\
\text { Posttest } \\
\text { Positive }\end{array}$ & $\begin{array}{l}6.90666 \\
4.42668 \\
9,309\end{array}$ & & \multirow[b]{2}{*}{$\begin{array}{l}2.606 \\
06\end{array}$} & \multirow[b]{2}{*}{$\begin{array}{l}3,4 \\
69\end{array}$} & 32 & $\begin{array}{l}5.6666 \\
7\end{array}$ \\
\hline $\begin{array}{l}\text { Pair } \\
2\end{array}$ & $\begin{array}{l}\text { Pretest } \\
\text { Neutral } \\
\text { Posttest } \\
\text { Neutral }\end{array}$ & $\begin{array}{l}4.13617 \\
1.07595\end{array}$ & & & & 32 & .002 \\
\hline
\end{tabular}

Based on the table. 3 , it is evident that the significance value from the results of testing the value of $t$ is 0,000 , smaller than the significance level $\alpha=0.05$. The conclusion obtained is that there are differences in the development Self-Esteem of healthy in junior high school students after and after being given positive feedback.

Based on the table, it is evident that the significance of the results of testing the value of $\mathrm{t}$ is 0002, smaller than the significance level $\alpha=0: 05$. The conclusion obtained is that there are differences in the development of Self-Esteem healthy in junior high school students after and after being given treatment Neutral Feedback.

Self-esteem can grow and develop which is certainly influenced by several factors. The factors that influence the development of self-esteem, which are as follows the main source for the development of self-esteem is yourself. We can enhance and lower self-esteem in accordance with our own feelings, someone whose healthy self-esteem is characterized by several characteristics including being always giving encouragement, motivation to yourself, always looking at what was done and on what was done [7]. Correspondingly, giving feedback is essentially one way of strengthening the process of student learning behaviour [19].

Someone who has self-esteem will be good at managing a failure they face. When the learning environment of Physical Education takes place, students often fail when doing the movements instructed by the teacher. This incident will lead students to a state of weak self-esteem. The existence of positive feedback will strengthen students 'confidence in being able to act so that they can improve self-esteem students'

This study found that giving positive feedback from teachers to students can enhance the development of selfesteem healthy. The facts found in the field by researchers that when given positive feedback such as good, good, great, great interesting and fun students increasingly show confidence in every activity in learning Physical Education. Not only on the day's learning but this also continues on the next learning so that self-esteem students in this class continues to increase and learning becomes more effective. Other evidence that indicates the self-esteem child's is increasing "sir, I tried again sir, sir, I just played, sir, don't be afraid, my father can really". That sentence is one form of successful giving positive feedback to children while learning in improving the development of selfesteem.

In the results of this study positive feedback is better able to increase self-esteem compared to neutral feedback. Correspondingly, that positive feedback had a more significant impact in promoting positive self-concept [19]. This is because neutral is too general so students do not directly feel to themselves. Giving positive feedback while learning will be able to develop aesthetic and social personal, self-concept, social skills, and good ways of communicating. For example, the child is more able to respect himself and prove that he is capable. Neutral feedback has little impact on the development of self-esteem in children due to the fact that giving feedback is general not to individual students themselves so there are still many students who do not have confidence in Physical Education learning.

\section{CONCLUSION}

Based on the above results it can be concluded that this research proves that giving positive feedback has a good influence in developing healthy self-esteem in junior high school students. Furthermore, giving positive feedback is better than giving neutral feedback on the development of healthy self-esteem in junior high school students.

\section{REFERENCES}

[1] D. Budiman, "Comparison of the effects of giving positive feedback (neutral feedback) in physical education learning on the formation of positive self concepts of elementary school students," 2008.

[2] R. Bailey, "Physical education and sport in schools: A review of benefits and outcomes," Journal of school health, vol. 76(8), pp. 397-401, 2006.

[3] J. Cecchini, C. González, A. Carmona, J. Arruza, A. Escartí and G. Balagué, "The influence of the physical education teacher on intrinsic motivation, self-confidence, anxiety, and pre-and post-competition mood states," European Journal of Sport Science, vol. 1(4), pp. 1-11, 2001.

[4] R. Lutan, "Principles of physical education approach to motion education in primary schools," Jakarta: Depdiknas Dirjen Dikdasmen In collaboration with the Director General of Sports, 2001.

[5] U. Orth, R.W. Robins and K.F. Widaman, "Life-span development of self-esteem and its effects on important life outcomes," Journal of personality and social psychology, vol. 102(6), pp. 1271, 2012.

[6] G. Chen, S.M. Gully and D. Eden, "General self-efficacy and self-esteem: Toward theoretical and empirical distinction between correlated self-evaluations," Journal of Organizational Behavior: The International Journal of Industrial, Occupational and Organizational Psychology and Behavior, vol. 25(3), pp. 375-395, 2004.

[7] S. Weinberg, D. Roberts, Gould, "Foundations of sport and exercise psychology," USA: Human Kinetics, 1995.

[8] R. Lutan, "Planning and learning strategy penjaskes.ppgk-2536 (module 1 to 2)," Jakarta: Ministry of Education and Culture Director General of Elementary Education Dikdasmen Directorate of Teacher Education and Technical Personnel D-II Equivalent Teacher Quality Improvement Project Section, 1998

[9] M. Standage, J.L. Duda and N. Ntoumanis, "A model of contextual motivation in physical education: Using constructs from selfdetermination and achievement goal theories to predict physical activity intentions," Journal of educational psychology, vol. 95(1), pp. 97, 2003.

[10] N. Ntoumanis, "A self-determination approach to the understanding of motivation in physical education," British journal of educational psychology, vol. 71(2), pp. 225-242, 2001. 
education," Journal of environmental psychology, vol. 31(1), pp. 1-13, 2011.

[16] A.S. Makmun, "Educational psychology teaching system devices," Bandung: PT Youth Rosadakarya, 1995.

[17] K. Luyckx, S.J. Schwartz, M.D. Berzonsky, B. Soenens, M. Vansteenkiste, I. Smits and L. Goossens, "Capturing ruminative exploration: Extending the four-dimensional model of identity formation in late adolescence," Journal of Research in Personality, vol. 42(1), pp. 58-82, 2008.

[18] Soesilowindradini. (ttn), "Developmental psychology (adolescence)," Surabaya: National Business, 1995.

[19] D. Harjasuganda, "The development of positive self-concepts in elementary students as a result of the application of feedback in the physical education learning process," Journals. Basic education, Number 9, 2008. 